\title{
The role and response of the Eastern Ontario Model Forest to the 1998 ice storm ${ }^{1}$
}

\author{
by Brian Barkley ${ }^{2}$ and Geoff $\mathrm{McVey}^{3}$
}

During the first week of January, 1998, a severe ice storm crippled much of eastern Ontario, western Quebec, northern New York and portions of the New England states. Although ice storms in this area are not unusual, this one was unique. It covered a huge geographic area and the freezing rain deposited (70-110 mm in parts of eastern Ontario and western Quebec), was roughly twice the previously recorded maximum (Savage 1998). The area affected in eastern Ontario roughly $m$ corresponded to the boundaries of the Eastern Ontario Model त Forest (EOMF) (Fig. 1). The land base of eastern Ontario is approxNimately 15000 square kilometres and is inhabited by over one million people. Approximately 88 percent of the productive forठี est cover is privately owned, with many parcels less than $\infty 40$ hectares. The "woods" industry contributes over $\$ 100$ milflion annually to the economy of eastern Ontario, supplying wood to over 240 wood using facilities and employing over 3700 peoin ple. Over 6500 landowners manage their woodlots as business हेventures to supply the local wood-using facilities. In addition, ofover 500 maple syrup producers, with a total of 300000 taps,

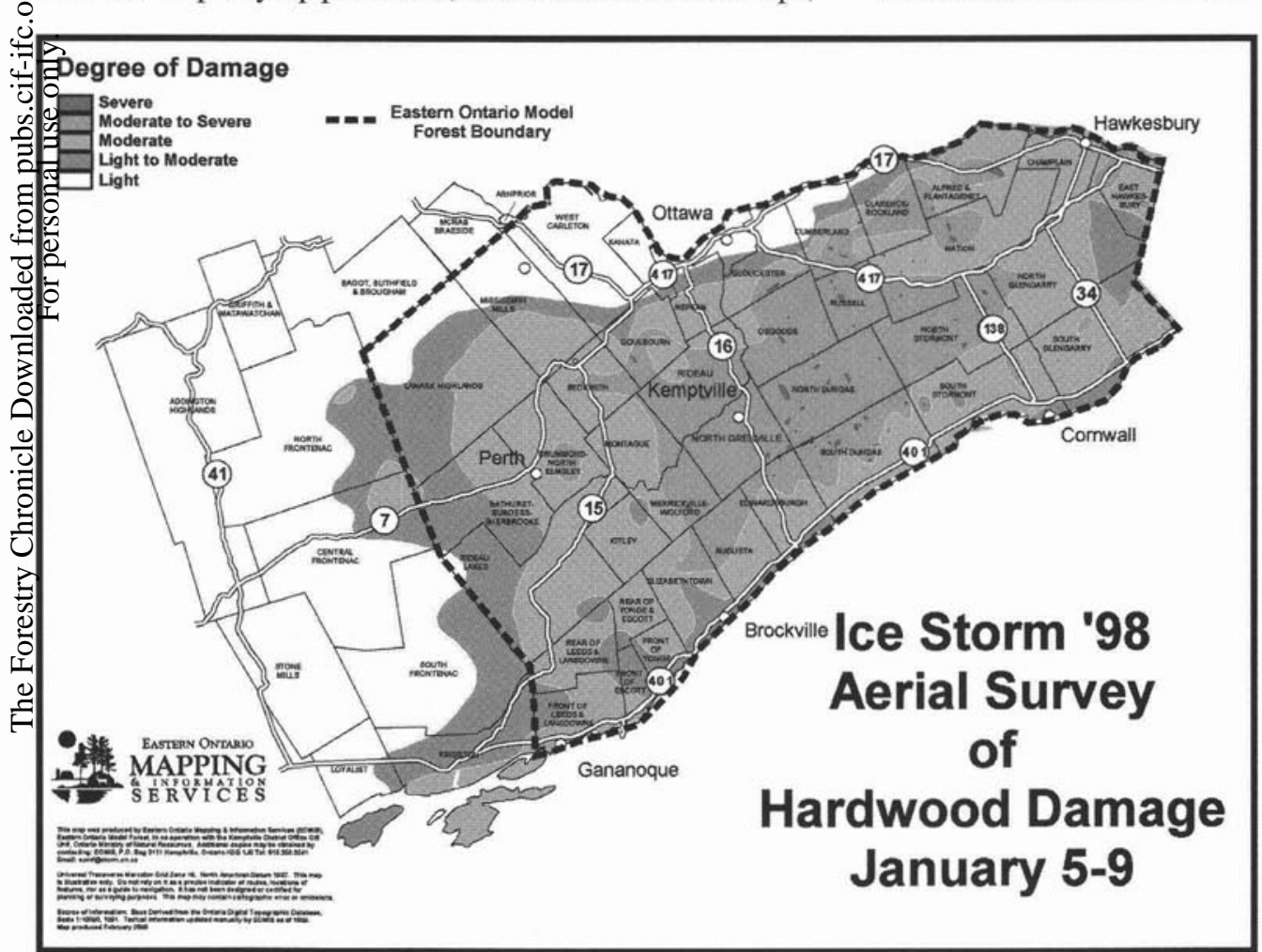

Fig. 1.

\footnotetext{
${ }^{1}$ Paper presented at the Ice Storm 1998 Forest Research Conference, Ottawa, October 19-22, 2000.

${ }^{2}$ General Manager, Eastern Ontario Model Forest, Kemptville, ON. E-mail: bbarkley@eomf.on.ca

${ }^{3}$ Field Coordinator, Ice Storm Forest Research and Technology Transfer Program, Kemptville, ON
}

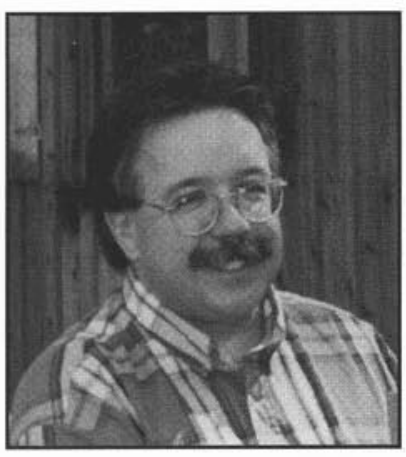

Brian Barkley

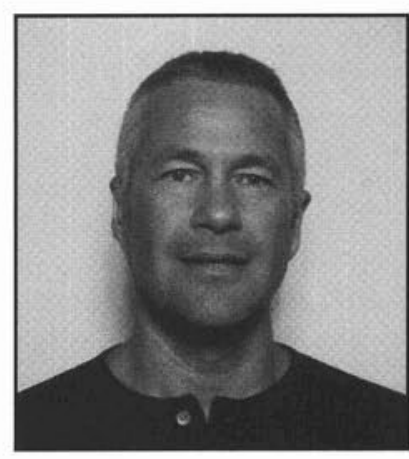

GeoffMcVey producing approximately $25 \%$ of the commercial maple syrup in Ontario were affected by the ice storm.

The EOMF is one of twelve Canadian Model Forest sites and has been in operation since 1992. Established to reflect the forest conditions of eastern Ontario, its primary goal is to promote the concept and practice of sustainable forestry through the cooperative efforts of its residents and supporters. There are numerous forest partners actively involved in the organization, all of which have an opportunity to define sustainable forest management as it pertains to their local area.

When the EOMF was formed, a number of key forestry-related issues were identified, but "ice damage" was not one of them. However, the processes and partnerships developed through the formation of the EOMF were effective in responding to this crisis in the forest. Crisis may be a strong word but it accurately described the overwhelming sense of loss to those who held dear the many values associated with the forests of eastern Ontario. Biologically, the ice storm provided a multitude of both positive and negative side effects. For those who were dependent upon the forest for income, the ice storm caused an economic crisis. Not only was there biological and economic loss, but a "crisis of spirit" soon developed for those who now had to dedicate time, energy and resources to post-storm cleanup activities.

The EOMF strives to balance respect, equity and empowerment: Listening to all ideas, concerns and questions; pool- 
ing of resources and knowledge; and the commitment to get on with the task at hand. After the many serious human welfare issues in the broader community were dealt with (shelter, restoration of hydro and phone services), people started thinking about the devastation to the forest and approaches to hasten its recovery. During this time, the EOMF provided a forum for local stakeholders to get together to raise questions and share information and knowledge. This clearing house provided an opportunity to move quickly and develop potential policy solutions in a "neutral" environment. Activities initiated by the EOMF eventually shifted into the domain of other groups/organizations and grew into active programs (Lautenschlager and Nielsen 1999).

This process moved along quickly. A meeting was held in the centre of the ice-damaged area (Kemptville, ON), on January 22, 1998, to: a) discuss and exchange information and observations on the impact of the storm on the forests of eastern Ontario; b) share knowledge and experience about how forests may respond in both the short- and long-term to the damage, and c) consider how best to respond to forest damage caused by the storm. Partners from New York State were also involved in discussions. Shortly thereafter (Feb 18, 1998), the ad hoc Ice Storm Forest Recovery Group was formed, facilitated by the EOMF and its ability to cross jurisdictional boundaries, both provincial and international, in order to draw together the most appropriate people. The importance of the EOMF in setting the stage for an organized response to the storm was described by Don Dodds, President of the Lanark and District Maple Syrup Producers Association. "People were quite concerned, as the income of many of the producers is maple syrup. We didn't have many financial resources, and we were not in any way prepared to deal with an emergency. Without the Model Forest it would have been a very disjointed approach."

One of the first priorities was to get information out to the local landowners. The consistent message from all partners to the public was: 1) safety first; 2) pause-don't panic, and 3) get proper help in assessing trees and woodlots. A set of work plans, based in part on combining local damage assessments with the Ontario Ministry of Natural Resources (OMNR) and Canadian Forest Service (CFS) aerial surveys, were developed to cover these and many other issues. Another high priority was providing Human Resources Development Canada (HRDC) with appropriate advice and information regarding the "Ice Storm Recovery Proposal" and the hiring of a local coordinator.

Contact was made with organizations in Quebec, New York, Vermont and New Hampshire to share as much information and experience as possible. Emphasis was also placed on the need to "share what we know" as soon as possible. A series of media releases, newsletters, seminars and workshops were organized and put into action. The annual Winter Woodlot Day held in Kemptville that February focussed on the ice storm. Local Stewardship Councils were very proactive in getting as much information as possible out to the public. The establishment of a local 1-800 telephone number, via the Landowner Resource Centre in Manotick, ON, was instrumental in providing information to the public who were demanding guidance and advice. At the same time, a number of other agencies were establishing various recovery programs such as tree planting initiatives (both urban and rural) for the coming spring.

Shortly after the ice storm, a partnership quickly developed between the Forest Science Committee of the EOMF and
Carleton University (Ottawa, ON), as an interim step in considering science aspects of post-damage forest recovery. Researchers there had developed a large database of information from field plots established prior to the storm. That database provided a rare opportunity to assess and analyse the damage from a "before and after" perspective.

On March 1, 1998 a joint federal/provincial agreement, the Canada-Ontario Agreement for the Ice Storm Economic Recovery Assistance Program, Annex A, Assistance for the Agricultural Sector and Rural Communities in Eastern Ontario, was signed. One of the components of that agreement, "Evaluation, Assessment and Advice," provided funding to support research, to evaluate and assess impacts of the storm and determine measures to accelerate recovery and mitigate negative economic effects. Shortly thereafter the Ice Storm Forest Science Committee was formed under the leadership of the OMNR with representatives from the EOMF, CFS and the Ontario Ministry of Agriculture, Food and Rural Affairs (OMAFRA). This committee was responsible for working with other government agencies and scientists identifying how best to address the key questions and science gaps, both from a short- and long-term perspective. The resultant research proposal was presented for review to a number of scientists from Ontario, Quebec, New York, Vermont and Pennsylvania (Lautenschlager and Nielsen 1999).

The ongoing "Ice Storm Forest Research and Technology Transfer" (ISFRATT), program is the result of this process. There are two project coordinators, Cathy Nielsen (OMNR, Kemptville), R.A. Lautenschlager (OMNR, Sault Ste. Marie), and one Field Coordinator (Geoff McVey, EOMF/OMNR, Kemptville). The summer of 2001 will be the last field season for the program. A complete report of the program and all findings will be published in 2002. In the meantime, our level of knowledge and understanding of the effect of the 1998 ice storm on the forests of eastern Ontario continues to increase.

In reviewing the response made by partners in the aftermath of the ice storm, many of the principles of the Naturalized Knowledge System as outlined by Henry Lickers of the Mohawk Council of Akwesasne have been illustrated (EOMF 1997, Lickers and Storey 1997). Cooperation is the key to survival-many organizations saw the value of voluntarily working together and agrees t $\mathrm{t} \Omega \mathrm{d} \Omega \mathrm{s} \Omega$. Knowledge is powerful only when shareda tremendous base of knowledge was pooled and used to guide recovery efforts as well as to formulate suitable hypotheses for research. Everything is connected to everything elsethe science effort used an integrated approach to look at the forest as a whole in the recovery process. The earth is our mother- researchers and others involved in post-damage efforts respect the forest and all it represents.

\section{References}

EOMF. 1997. Setting the stage for seven generations - Eastern Ontario Model Forest - Supplement to the phase II strategy. Kemptville, ON.

Lickers, H.A. and P.A. Storey. 1997. Partnership building for sustainable development: A First Nations perspective from Ontario. In O.T. Bouman and D.G. Brand (eds.) Sustainable forests: Global challenges and local solutions. Food Products Press, Binghampton, NY.pp. 149-162.

Lautenschlager, R.A. and C. Nielsen. 1999. Ontario's forest science efforts following the 1998 ice storm. For. Chron. 75(4): 633-641.

Savage, S. 1998. The worst ice storm in Canadian history? (and) A closer look at a rare event. From: www.tor.ec.gc.ca/events/icestorm98/icestorm98_html. 